IRA-International Journal of Education \& Multidisciplinary Studies ISSN 2455-2526; Vol.05, Issue 03 (2016)

Pg. no. 147-152

Institute of Research Advances

http://research-advances.org/index.php/IJEMS

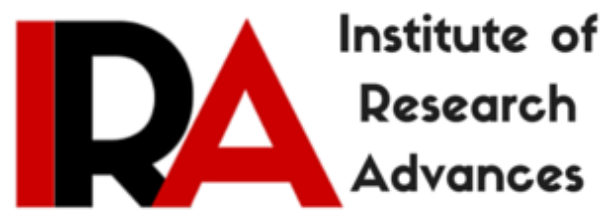

\title{
A Societal Analysis of Buddha in a Traffic Jam
}

\author{
Dr. A. Sunkanna
}

Assistant Professor

Silver Jubilee Govt. College (A)

Kurnool, Andhra Pradesh- 518001, India.

Type of Review: Peer Reviewed.

DOI: http://dx.doi.org/10.21013/jems.v5.n3.p2

\section{How to cite this paper:}

Sunkanna, A. (2016). A Societal Analysis of Buddha in a Traffic Jam. IRA International Journal of Education and Multidisciplinary Studies (ISSN 2455-2526), 5(3), 147-152. doi:http://dx.doi.org/10.21013/jems.v5.n3.p2

(C) Institute of Research Advances

(cc) EY-NC

This work is licensed under a Creative Commons Attribution-Non Commercial 4.0 International License subject to proper citation to the publication source of the work.

Disclaimer: The scholarly papers as reviewed and published by the Institute of Research Advances (IRA) are the views and opinions of their respective authors and are not the views or opinions of the IRA. The IRA disclaims of any harm or loss caused due to the published content to any party. 
After a thorough watch of the film several times, Buddha in a Traffic Jam is considered to be an autobiographical film based on its writer \& director Vivek Agnihotri's life. Based on true life incidents, its treatment is that of a new age political drama with a unique chapter wise approach to relevant topics leading to its climax. His storytelling format is like a book which takes off from prologue to epilogue and has chapters in between which are decently interesting. The film is an initiative by one of the top Business schools of the world, Indian School of Business, Hyderabad and this is the first Indian film ever based and shot in a B school. The script seems to have a forced irony and drama element to it which instantly puts one off.

Film explores how certain universities are brainwashing students to become intellectual terrorists. The film also takes on various themes of corruption, campus politics, moral policing, crony socialism and the aspirational India wiping it clean of its middlemen. It probes deep into the relevance of socialism and capitalism in a poverty and corruption ridden India seeking to become a superpower.

It is very interesting to see that the prologue of film opens in $2000 \mathrm{BC}$, with a tribal underclothed villager chopping wood with an axe, and in again 2014, with the underclothed villager is still hacking away at it in the same place, which is referred by the Director Bastar, and has reflections unchanged since ages. Whilst the villager was chopping, an outsider comes to the tribals and asks for a glass of milk. They inform the family that they are going organize a campaign on behalf of the govt, but the villager was reluctant to consent and he is forced to accept it. Soon after a group of naxals met the same family and force them to support the cause of their fight. The entire episode reflects that the village family supports neither the outsiders nor the naxals. The harassment of a tribal family by the two powers indicate how the tribals are entangled between them. One can understand easily that the family is now caught in the crossfire of the government-Naxalite fight.

The film has everything about Naxalism, Adivasis, capitalism, socialism and more importantly communism in its plot.

The prologues shifts to see where a group of students at a Hyderabad B-school, are hanging out at a pub. Over beer, cigarettes, and joints, they have futile discussions about ideologies and beliefs, peppered with good-natured cracks at each other.

Pooja, who plainly acts like a vamp, is now drunk and starts talking about the concept of souls in human beings and animals. After proclaiming she is a 'bitch', she proceeds to sing a song called 'I'm A Bitch', during which she climbs up on the top and strips down her top and shows her pink bra. Meanwhile, everyone around her, instead of controlling her, sings along with her like they're all having a moment and she's their brand ambassador. Unfortunately she is humiliated by the Police crackdown on the pub.

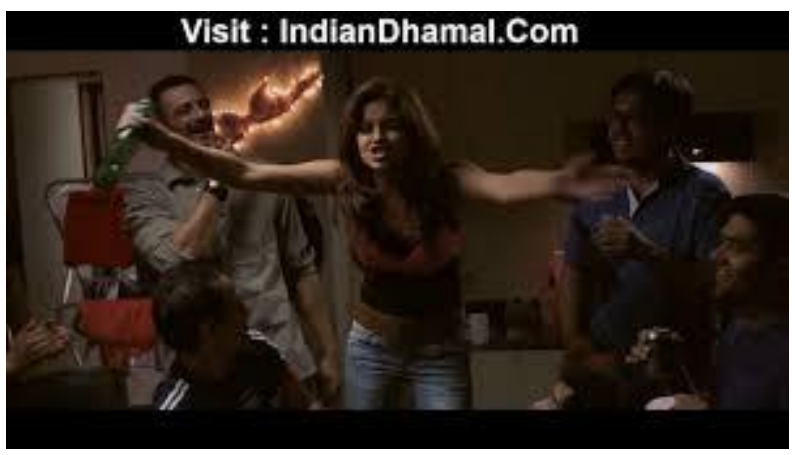


Vikram Pandit the protagonist of the film is an IIT Delhi- New York returned chap. blazes across social media to hit back at moral policing against the girl in night clubs through his 'Pink Bra' campaign. This young lad becomes an overnight sensation after a successful social media campaign against the radical fundamentalism of moral policing in India. This goes radically viral on the internet.

He also learns that overzealous moral police are affiliated to political parties. And finally they all become pink bra heroes in overnight.

The second chapter "A Secret Game" takes a close look at one of the professors Rakesh Batki of the B School, who is delivering lecture on "Corruption is Good". Professor Batki tells his students "as it greases the wheels of economy." Professor is indeed the captivating teacher and so the students always rally around him. The Professor quotes that corruption is much needed grease for good administration in India. He also states that corruption is like a tonic for economical stimulation in most of the govt. offices. His students, however, do not agree, especially Pandit.

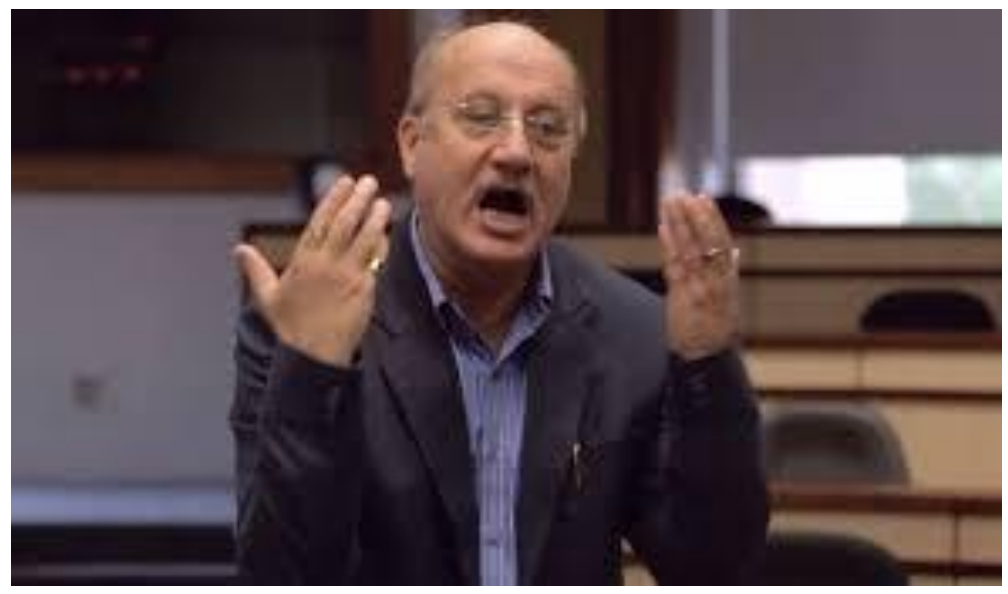

Looking at Vikram's skills, the professor starts to share with his students the materials of writing that he wants Vikram to spread through the youth calling his own. Giving talks on

It is well understood that the Professor tries to net students with his speeches in the class. Vikram catches the attention of the Professor and soon he is asked to play a secret game. Under the secret game. Vikram reads this file and a new person is born from inside him and he starts work to bring changes in society.

Vikram becomes a popular student speaker after a couple talks on the issues of corruption and the injustice of the downtrodden.

He takes the issues of Kashmir and Adivasis, which are manipulated by the terrorists and Maoists respectively in the country.He feels that the biggest enemies in the country are the people who work in the govt. offices. He slowly realizes the political scenario around him, the agony of the deprived in India. 


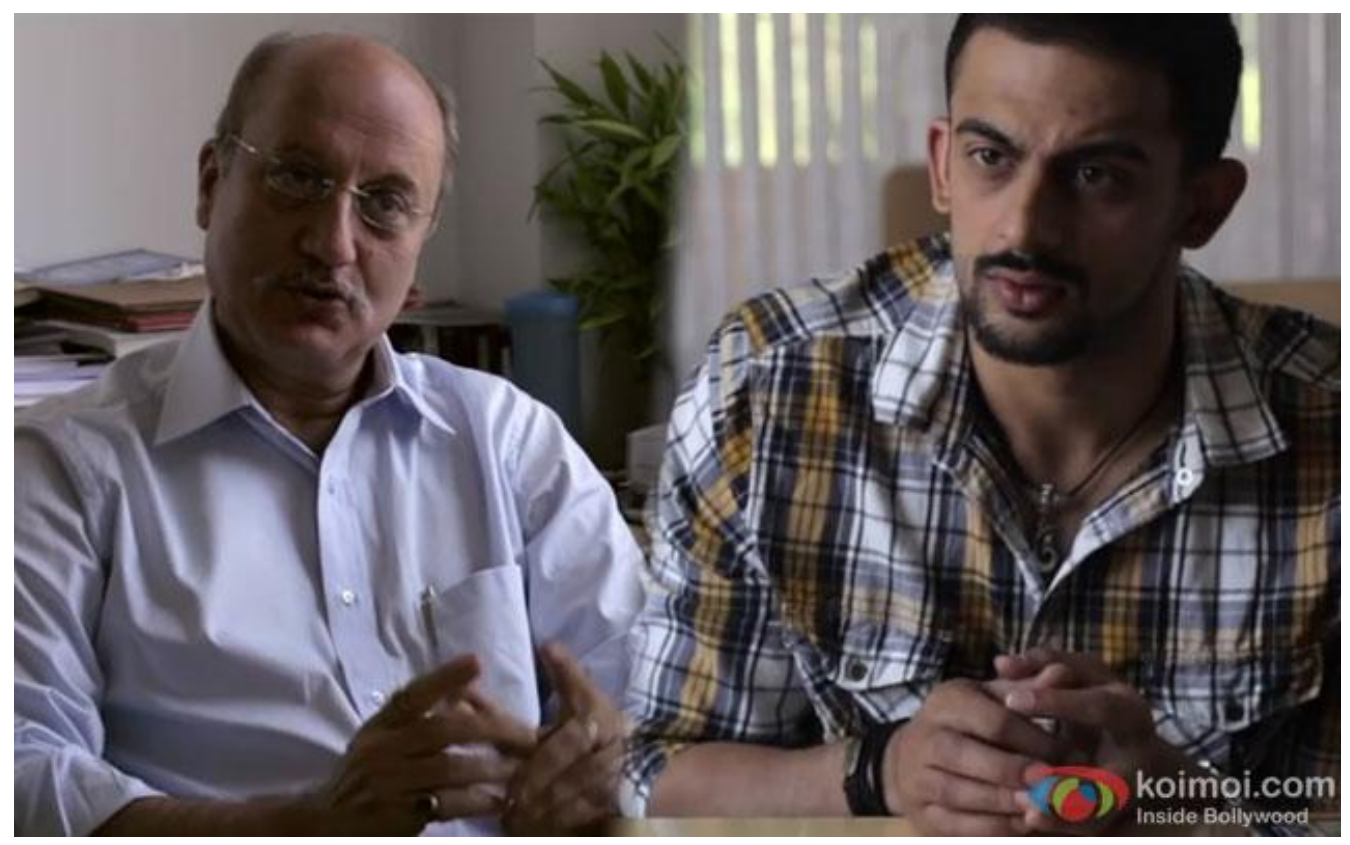

This chapter exposes the alleged link between the Naxals, NGOs, academia and the intelligentsia and probe how certain universities brainwash students to become intellectual anti-social elements. It also throws a debate on the student-faculty relationship.

He delivers a thought provoking speech where he convinces that India needs freedom from mediocrity, inefficiency and incompetence.

But in one of the scenes, he gives out the silliest of dialogue with Professor's wife like, "A sexy woman has no substance and women with substance are rarely sexy and if you are looking for both then they are married women"

When we see it on a larger scale, it looks like the protagonist aspires to solve all of these problems by just involving the beer-drinking, weed-smoking, unhesitant about casual sex, social-media crazy youth. They don't have clues about their surroundings. They are not aware about the red tape violence.

\section{The Potters Club:}

In the very beginning of the chapter, there is quite exciting conversation between Vikram and Additional Director General of Police regarding the two issues of terrorism and Naxalism. He calls the Naxals as the traitors who are responsible for the death of the common civilians in the country. This chapter preaches us what the situation of tribes in India is. Why the concept of 'rich are getting richer and poor are getting poorer' prevails and how corruption is connected to this and of course why Naxalism is a much graver issue than Kashmir in India today.

The club is the brainchild of Bhekti's wife Sheetal She is helped by Charu Siddhu who runs an NGO that works for tribal welfare in Bastar. They are looking forward to a huge government grant for the tribal people. However, with the increasing cases of Maoists attack on civilians the Government decides to stop funding of NGOs because they believe that these funds reach the antisocial elements. With Charu's help, Sheetal employs women from Bastar villages to make pots. When a 
crucial grant from the Centre is stopped because of a crackdown on non-governmental groups working in the poor region, the professor gives his students an assignment to raise funds for it. Ranjan challenges Vikram to create real change by coming up with a plan to sell the unsold pots to make up for the loss of the government grant.

After a lot of brainstorming Vikram comes up with a modern day remedy that can bypass all red tape and political hurdles. He comes up with an idea that his business model turns out to be an extremely well as it wipes out all the middlemen from the business. The problem is primeval but the remedy is contemporary. Vikram offers a modern day solution that can bypass all hurdles.

. "Let's cut out the middleman... Christie's and eBay are ready to buy." The most disturbing factor due to the globalization is the fruits are not reaching to the common Man

Professor denies that it is a 'risk not worth taking'. He defines it as having political undertones.

He blames Vikram that his idealogy is nothing but political mindset and moreover he doesn't want to change B School as corporate sector for the business. The director establishes this business idea will lead to the impossibility of money laundering carried out by the Naxals in the tribal area. Sheetal, however, cannot see reason behind her husband's abrupt dismissal of a brilliant idea. Gradually as under-layers of the story surface and veils are lifted from the faces of people around him, Vikram realizes what he is up against; he must find a way out of the vicious circle.

However he is unaware of the fact that he is about to become a part of a dangerous ploy that would put his life at risk and unmask several people around him.

\section{Red salute:}

This chapter opens up with the Maoists killing of an innocent civilian, who is labeled as the CRPF informer. We find a formal meeting between Maoists and the Professor, who is said to the recruiter for the red tape members.

When the Maoists demand for the abduction of Vikram, it is well understood that he gets entangled between two corrupt facets of India - Socialism and Capitalism, both of which are deeply rooted in India.

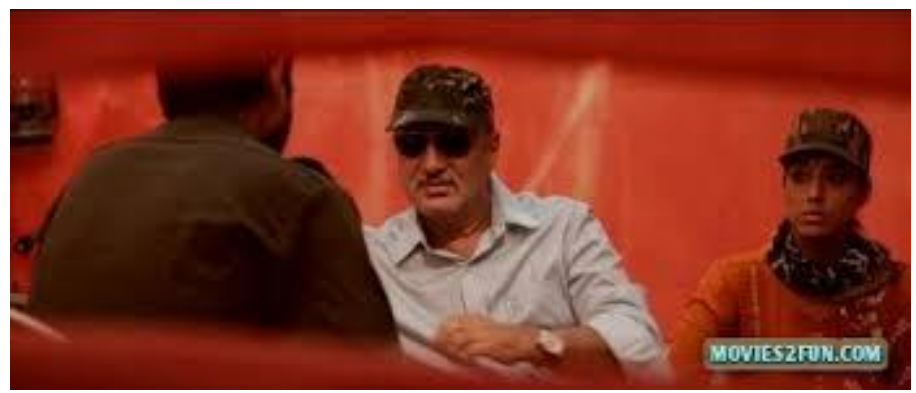

To put in a nut shell, Agnihotri brings in the vivid picture of India at play. There's moral policing, student party, Maosits movement besides police and government harassment of the poor tribals. Then, there are the outsiders, the urban youth, who want to make a difference but who are soon silenced, branded as traitors themselves. This turn of events is too hot for comfort for Vikram who just wants to make a 
difference. Agnihotri tries to provide a solution to every burning issue. But it turns out to be clear case of too many cooks spoil the dish.

At the end the audience is absolutely confused to understand the following issues where the director failed.

Socialism in the era of Global Capitalism is only for bailing out so-called corporations socializing the cost to research and develop then privatizing its profits such as Apple's iphone, NASA technologies used by Boeing, the internet etc, Socialism today is a method to underwrite social cost which businesses would otherwise be paying for through higher taxes, such as roads, hospitals and military. Capitalism has devoured Socialism and spat out a disfigured monstrosity the likes we've never seen and its frightening consequences are unraveling with protectionist nationalist politics in response to inequality and the inability to face the looming catastrophic disaster of climate change

Do we really believe that most of our reputed IIT's and B Schools are being infiltrated and produce antisocial element?

Is communism or Maoism the biggest threat to the integrity of our mother country rather terrorists?

Mohar Basu of the Times of India said: "Quoting from the film, the best thing that can be said about Buddha in a Traffic Jam is that we love the ideas Vivek brings forth but we are not in love with them. It lacks outrage and treads familiar ground."

Mulvey believes that women are in fact "the bearer of meaning and not the maker of meaning," which suggests that women are not placed in a role where they can take control of a scene, instead they are simply put there to be observed from an objectified point of view.

Ref: Film Theory 101 - Laura Mulvey: The Male Gaze Theory

\section{References:}

1. Exclusive Interview: Vivek Agnihotri Exposes 'Intellectual Mafia' Through Buddha In A Traffic Jam: https://www.youtube.com/watch?v=VYpPKJtcjbU

2. Exclusive interview in DNA (Daily News \& Analysis) with Kanchan Srivastava Fri, 6 May 201606:35am, DNA

3. Buddha In A Traffic Jam Movie Review: Mohar Basu, TNN, Updated: May 12, 2016 Times of India

4. Buddha In A Traffic Jam review: All hype, no substance: Hindustan Times : May 14, 2016

5. Ref: Film Theory 101 - Laura Mulvey: The Male Gaze Theory

6. http://www.hindustantimes.com/movie-reviews/buddha-in-a-traffic-jam-review-all-hype-nosubstance/story-yBRIrqNwxQNR65QVVsyyfN.html

7. https://yourstory.com/2016/05/7-reasons-buddha-in-a-traffic-jam/

8. https://www.youtube.com/watch? v=VYpPKJtcjbU 